\section{Britain plans broad strategy on genome, approves therapy}

London. Keen to exploit Britain's strengths in molecular biology and genetics, the government is planning a national strategy for human genome research, drawing on the skills and interests of university scientists, research councils, medical charities and the pharmaceutical industry. Last week's announcement came as approval was granted for the country's first gene-therapy experiments.

As a first step towards a national programme, the Office of Science and Technology has commissioned a broad-ranging report on the state of genome research in

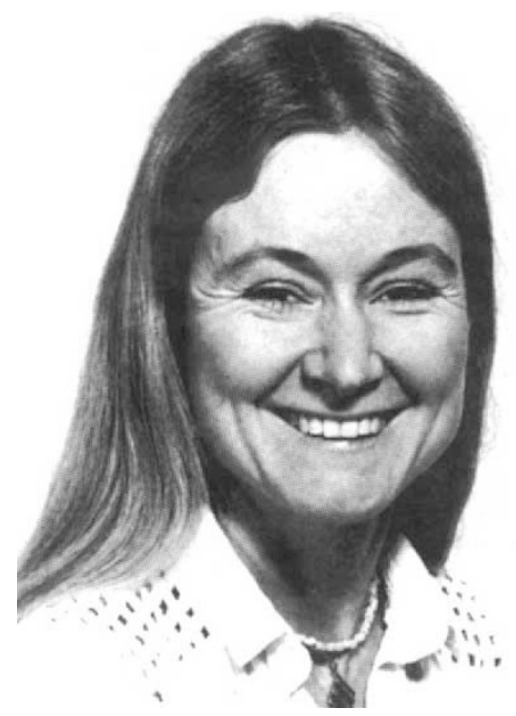

Kay Davies

Britain, to be delivered by the end of the year. The report will cover not only research and training related to the human genome, but also the scope of (and presumably barriers to) commercialization of genome-related technologies and the ethical questions involved.

The report will be written by a small group of experts chaired by Kay Davies, recently appointed director of the Medical Research Council (MRC)'s new Clinical Sciences Centre in London. Other members of the review group will be announced after the first meeting on 5 February of an Advisory Committee on Human Genome Research, which has just been set up by William Waldegrave, the cabinet minister responsible for science.

Sir William Stewart, the government's chief scientific adviser, will head the advisory committee. In addition to the heads of two research councils and two charitable foundations (the Wellcome Trust and the Imperial Cancer Research Fund), the advisory committee will include the research directors of four of Britain's largest SmithKline Beecham and the Wellcome Foundation.

In announcing the creation of the advisory committee, Waldegrave emphasized the way in which genome research provides what he described as "the basis for the most modern techniques of gene therapy". Coincidentally, a research team headed by Roland Levinsky, head of the University of London's Institute of Child Health, received on the same day the go-ahead for the experimental transplantation of a functioning adenosine deaminase (ADA) gene into the bone marrow cells of a child suffering from ADA deficiency.

Similar experiments have already been carried out in both the United States and Italy but in those cases, only T cells were altered and the process had to be repeated at regular intervals. In contrast, the British stem cells as well as $T$ cells which, if successful, will result in one of the first permanent implantations of a manipulated human gene.

The ADA experiments are proceeding after the decision by a government advisory committee on gene therapy, chaired by Sir Cecil Clothier, that it had no ethical objections to the experiment, although it emphasized the need for close monitoring of the patient's progress.

Also last week, the MRC announced that, given the increasing interest in gene therapy - one of the principal aims of the new Clinical Sciences Centre is to stimulate work in this field - it is setting up a steering committee to ensure that such work is carried out responsibly. In particular, the steering committee will be responsible for ensuring that clinical trials of gene therapy conducted by MRC scientists are "well planned and properly conducted" as well as encouraging interaction with industry.

Those keen to proceed with gene-therapy experiments, however, are still waiting official endorsement from the government. This had been expected last week (see Nature 361,$285 ; 1993$ ) in the form of a decision to set up a permanent body to oversee this work, as proposed by the Clothier committee last year, but has apparently been delayed for what a government spokesman described as "administrative reasons".

The government's response is still thought to be imminent. "It is time that we had a response", Dai Rees, secretary to the MRC, said last week. "Things are moving ahead fast in this field, and there is a danger that the government could start to hold things up." pharmaceutical companies: Glaxo, ICI, technique will involve the manipulation of
INDIA IN BRIEF

New Delhi. The Indian government has stopped all field releases of an insect introduced to combat a noxious weed because it has begun to feed on a major crop. Eight years ago, the government imported the Mexican beetle Zygogramma bicoloratia to control the weed Parthenium hysterophorus, which accompanied grain imported from the United States in the 1950s, but last year the insect was found feeding on sunflower, from which oilseed is derived. Tests on the beetle's affinity to 200 indigenous plants, done before the experiment was launched, are being repeated, but there is also the possibility that a species closely related to $Z$. bicoloratia and known to be a sunflower pest elsewhere in the world was unwittingly imported in the original batch from Mexico.

India plans to proceed with large scale trials of a birth-control vaccine that the World Health Organization (WHO) says is unsafe. The Indian National Institute of Immunology, which developed the vaccine, says that the criticism is rooted in a desire by WHO to promote its own vaccine, developed in the West. Both vaccines aim to neutralize human chorionic gonadotropin (hCG), produced at the time of conception and essential for development of the fetus. The Indian vaccine uses purified beta subunit of hCG as an antigen. which WHO officials say can be harmful to healthy women because it also reacts to luteinizing hormone (LH). The WHO vaccine is a synthetic peptide representing a small fragment of the beta hCG that does not react with $L$ H. A phase-3 trial on 10,000 women is planned using slow-release capsules intended to give protection against pregnancy for as long as two years.

- India has decided to drop its attempt to buy a Cray YMP supercomputer after the United States imposed what India calls "unacceptable" conditions on the sale. The deal, proposed in 1988 . soured largely because US officials impose greater limitations on exports to countries that have not signed the Nuclear Non-Proliferation Treaty; in India's case, those included having a person from Cray onsite at all times and restricted physical access to the machine itself. The Indian Institute of Science in Bangalore, which intended to use the supercomputer for basic research in crystallography and biology, has already spent $\$ 1$ million on new facilities to handle the machine. C. R. Rao, director of the institute, calls the rejection "a blessing in disguise" and says the institute will instead install its own massively parallel processing computer, called PARAM, with workstations throughout the campus.

K.S. Jayaraman 